Kalpa Publications in Civil Engineering
Volume 1, 2017, Pages 1-6
$\begin{gathered}\text { ICRISET2017. International Conference on Re- } \\ \text { search and Innovations in Science, Engineering } \\ \text { \&Technology. Selected papers in Civil Engineering }\end{gathered}$

\title{
Design and Seismic Analysis of Ground Supported Water Tank
}

\author{
Rishi Dave ${ }^{1}$, Rahul Patel ${ }^{1}$ and Prutha Vyas ${ }^{2}$ \\ ${ }^{1}$ Under graduate Student, Civil Engineering Department School of Engineering and Technology, \\ Navrachana University, Vadodara, India \\ ${ }^{2}$ Assistant Professor, Civil Engineering Department School of Engineering and Technology, \\ Navrachana University, Vadodara, India \\ rishidave30@gmail.com, rpatel1353@gmail.com,pruthav@nuv.ac.in
}

\begin{abstract}
The ground supported tanks are firmly attached with ground and tank walls are subjected to hydrostatic as well as hydrodynamic pressure due to seismic forces. Base of the tank is subjected to weight of water and pressure of soil. Top of the tanks may be covered and is designed by using IS 3370:2009 Part (I, II) [4] and IS 1893:2007 (part-2) draft code[3] is used for the seismic analysis of the tank. This paper gives idea behind the design of liquid retaining structure (rectangular ground supported water tank) using working stress method. This paper includes the seismic analysis and design of the tank. The values are obtained with the help of spreadsheet program. Analysis of ground supported water tank has been carried out and relationship between tank capacity with moment capacity and reinforcement area, base shear with impulsive height and overturning moment with convective height is derived.

\section{Introduction}

Water tank is designed to store water. As water is basic need for all living organisms it is necessary to keep water tank safe and functional during earthquake. Seismic design and analysis of water tank is very important aspect for structure engineers. Elements of ground water tank include base slab and tank walls. Tank should be resting on ground firmly, here base slab will not be a critical element and hence only nominal reinforcement should be required. When a tank containing liquid is subjected to earthquake ground motion tank walls and liquid is subjected to horizontal acceleration. Due to this tank walls will subjected to hydrodynamic pressure. To understand hydrodynamic pressure spring mass model from IS: 1893:2007 (part-2) draft code[3] can be considered. The liquid in the lower portion of tank behaves like a mass rigidly attached with tank wall. This liquid mass is termed as impulsive mass which moves along with the wall. Impulsive hydrodynamic pressure acts on tank walls due to Impulsive liquid mass. Liquid mass in upper region of tank experience sloshing motion. This mass is termed as convective liquid. Thus total liquid mass gets divided into two parts i.e. impulsive mass and convective mass. This study derives the relationship between tank capacity with moment capacity and reinforcement area, base shear with impulsive height, overturning moment with convective height using computer subroutines and design of ground supported water tank by working stress method.
\end{abstract}

C.D. Modhera, G.J. Joshi, D. Soni, I.N. Patel, A.K. Verma, L.B. Zala, S.D. Dhiman, D.R. Bhatt, J.M. Rathod, B.C. Goradiya, M.S. Holia and D.K. Patel (eds.), ICRISET2017 (Kalpa Publications in Civil Engineering, vol. 1), pp. 1-6 
Spring Mass Model

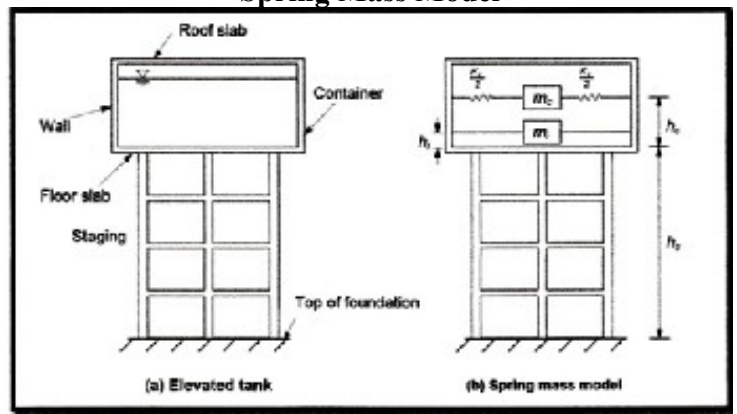

Figure 1: Spring Mass Model For Water Tank As Per Is:1893-2007[3] Draft Code

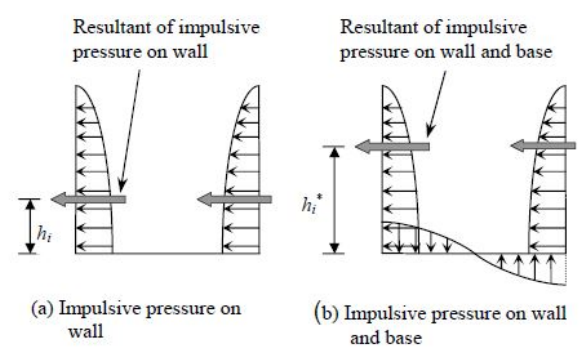

Figure 2: Hydrodynamic Pressure On Water Tank

$\boldsymbol{h}_{\boldsymbol{i}}=$ the height at which impulsive hydrodynamic pressure acts on tank walls from bottom of the tank. $\boldsymbol{h}_{\boldsymbol{i}}{ }^{*}=$ the height at which the of impulsive pressure on wall and base is located from the bottom of tank wall.

The mass of liquid in upper region of the container of tank will undergoes sloshing motion. This mass termed as convective mass.

\section{Design of Ground Supported Tank}

The tanks may be circular or rectangular in shape. For rectangular shape tank it is preferable that longer side should not be greater than twice the smaller side. Moments are caused in two directions of the wall i.e. both in horizontal as well as in vertical direction. If the length of the wall is more than its height, the maximum moments will be in the vertical direction, i.e., the wall bends as vertical cantilever. When the height is larger than to its length, the moments will be in the horizontal direction and wall bends as a thin slab supported on edges. The walls are designed both for direct tension and bending moment.

For design of tank walls as continuous frame subjected to Hydrostatic pressure varying from zero at top to maximum at $\mathrm{H} / 4$ or $1 \mathrm{~m}$ from base slab, whichever is more. The bottom portion of $\mathrm{H} / 4$ or $1 \mathrm{~m}$ is designed as cantilever.

For bending, walls are subjected to direct tension caused by hydrostatic pressure on the walls.

It is necessary to design it for both direct tension and bending moment. The bending moment in the walls are calculated by moment distribution method.

Design steps for ground supported water tank

1. Determination of dimension of the tank

2. Design of long walls

3. Design of short walls

4. Base slab is checked against uplift.

5. Design of base slab 
Data: capacity-80000 lit, depth of tank container- $3.35 \mathrm{~m}$, free board- $0.15 \mathrm{~m}$, diameter of bars- 8,10 , $12,16 \mathrm{~mm}$, compressive strength of concrete- $25 \mathrm{MPa}$

\begin{tabular}{|c|c|c|}
\hline Design & Description & Program value \\
\hline \multirow{8}{*}{$\begin{array}{l}\text { Design } \\
\text { of } \\
\text { Section }\end{array}$} & Grade of steel & $\mathrm{Fe}-415$ \\
\hline & $\mathrm{d}_{\text {provided }}$ & $225 \mathrm{~mm}$ \\
\hline & $\mathrm{D}_{\text {provided }}$ & $260 \mathrm{~mm}$ \\
\hline & $\begin{array}{l}\text { Direct tension in } \\
\text { long wall }\end{array}$ & $50 \mathrm{kN}$ \\
\hline & $\begin{array}{l}\text { Direct tension in } \\
\text { short wall }\end{array}$ & $75 \mathrm{kN}$ \\
\hline & $\mathrm{A}_{\mathrm{st}}$ & $3254 \mathrm{~mm}^{2}$ \\
\hline & Reinforcement & $\begin{array}{l}\text { 20mm \#@90mm } \\
\mathrm{c} / \mathrm{c}\left[3489 \mathrm{~mm}^{2}\right]\end{array}$ \\
\hline & $\begin{array}{l}\text { Steel at center of } \\
\text { span }\end{array}$ & $2453 \mathrm{~mm}^{2}$ \\
\hline \multirow{4}{*}{ Cantilever portion } & $\mathrm{A}_{\mathrm{st}}$ & $300.36 \mathrm{~mm}^{2}$ \\
\hline & Moment & $5.82 \mathrm{kNm}$ \\
\hline & Diameter of bar & $8 \mathrm{~mm}$ \\
\hline & Reinforcement & $\begin{array}{c}8 \mathrm{~mm} \# @ 160 \mathrm{~mm} \\
\mathrm{c} / \mathrm{c}\end{array}$ \\
\hline \multirow{3}{*}{ Distribution Steel } & $\mathrm{A}_{\mathrm{st}}$ & $780 \mathrm{~mm}^{2}$ \\
\hline & Steel on each face & $390 \mathrm{~mm}^{2}$ \\
\hline & Reinforcement & $\begin{array}{c}8 \mathrm{~mm} \# @ 120 \mathrm{~mm} \\
\mathrm{c} / \mathrm{c}\end{array}$ \\
\hline \multirow{4}{*}{ Roof slab } & $\mathrm{d}$ & $214 \mathrm{~mm}$ \\
\hline & $\mathrm{D}$ & $240 \mathrm{~mm}$ \\
\hline & $\mathrm{A}_{\mathrm{st}}$ & $317 \mathrm{~mm}^{2}$ \\
\hline & Reinforcement & $\begin{array}{c}8 \mathrm{~mm} \# @ 150 \mathrm{~mm} \\
\mathrm{c} / \mathrm{c}\end{array}$ \\
\hline \multirow{3}{*}{ Base Slab } & $\mathrm{A}_{\mathrm{st}}$ & $2415 \mathrm{~mm}^{2}$ \\
\hline & $\mathrm{D}$ & $240 \mathrm{~mm}$ \\
\hline & Reinforcement & 8mm \#@170 c/c \\
\hline
\end{tabular}

Table 1 : Design Results Of Ground Supported Water Tank

\section{Seismic Analysis of Ground Supported Water Tank}

\begin{tabular}{|c|c|c|}
\hline \multirow{2}{*}{ Time period } & Description & $\begin{array}{c}\text { Program } \\
\text { value }\end{array}$ \\
\cline { 2 - 3 } & Impulsive mode $\left(\mathrm{T}_{\mathrm{i}}\right)$ & $0.16 \mathrm{sec}$ \\
\hline \multirow{7}{*}{ Base shear } & $\begin{array}{c}\text { convective mode }\left(\mathrm{T}_{\mathrm{c}}\right) \\
\text { At bottom of wall in } \\
\text { implusive mode }\left(\mathrm{V}_{\mathrm{i}}\right)\end{array}$ & $2.85 \mathrm{sec}$ \\
\cline { 2 - 3 } & $\begin{array}{c}\text { At the bottom of wall in } \\
\text { convective mode }\left(\mathrm{V}_{\mathrm{c}}\right)\end{array}$ & $115 \mathrm{kN}$ \\
\cline { 2 - 3 } & $\begin{array}{c}\text { Total base shear at the } \\
\text { bottom of wall }(\mathrm{V})\end{array}$ & $509 \mathrm{kN}$ \\
\hline \multirow{2}{*}{} & $\begin{array}{c}\text { Bending moment in } \\
\text { impulsive mode }\left(\mathrm{M}_{\mathrm{i}}\right)\end{array}$ & $656 \mathrm{kNm}$ \\
\hline
\end{tabular}




\begin{tabular}{|c|c|c|}
\hline \multirow{2}{*}{$\begin{array}{c}\text { Moment at } \\
\text { bottom of tank } \\
\text { wall }\end{array}$} & $\begin{array}{l}\text { Bending moment in } \\
\text { convective mode }\left(\mathrm{M}_{\mathrm{c}}\right)\end{array}$ & $200 \mathrm{kNm}$ \\
\hline & Total bendingmoment & $686 \mathrm{kNm}$ \\
\hline \multirow{3}{*}{$\begin{array}{l}\text { Over turning } \\
\text { moment }\end{array}$} & $\begin{array}{l}\text { At the bottom of the } \\
\text { base slab in impulsive } \\
\text { mode }\left(\mathrm{M}_{\mathrm{i}}^{*}\right)\end{array}$ & $2526.65 \mathrm{kNm}$ \\
\hline & $\begin{array}{c}\text { At the bottom of the } \\
\text { base slab in convective } \\
\text { mode }\left(\mathrm{M}_{\mathrm{c}}{ }^{*}\right)\end{array}$ & $792.63 \mathrm{kNm}$ \\
\hline & $\begin{array}{c}\text { Total overturning } \\
\text { moment at the bottom of } \\
\text { base }\left(\mathrm{M}^{*}\right)\end{array}$ & $2648 \mathrm{kNm}$ \\
\hline \multirow{5}{*}{$\begin{array}{l}\text { Hydrodynamic } \\
\text { pressure }\end{array}$} & $\begin{array}{l}\text { Impulsive pressure at the } \\
\text { base of wall }(\mathrm{Y}=0)\left(\mathrm{P}_{\mathrm{iw}}\right)\end{array}$ & $3.9 \mathrm{kN} / \mathrm{m}^{2}$ \\
\hline & $\begin{array}{c}\text { Impulsive pressure on } \\
\text { top of base slab }(\mathrm{Y}=0) \\
\left(\mathrm{P}_{\mathrm{ib}}\right)\end{array}$ & $3.37 \mathrm{kN} / \mathrm{m}^{2}$ \\
\hline & $\begin{array}{l}\text { Convective pressure at } \\
\text { the base of wall }(\mathrm{Y}=0) \\
\left(\mathrm{P}_{\mathrm{cw}}\right)\end{array}$ & $0.14 \mathrm{kN} / \mathrm{m}^{2}$ \\
\hline & $\begin{array}{c}\text { Convective pressure at } \\
\qquad \mathrm{Y}=\mathrm{h}\left(\mathrm{P}_{\mathrm{cw}}\right)\end{array}$ & $0.41 \mathrm{kN} / \mathrm{m}^{2}$ \\
\hline & $\begin{array}{c}\text { Convective pressure on } \\
\text { top of base slab }(\mathrm{Y}=0) \\
\left(\mathrm{P}_{\mathrm{cb}}\right)\end{array}$ & $0.137 \mathrm{kN} / \mathrm{m}^{2}$ \\
\hline $\begin{array}{l}\text { Pressure due } \\
\text { to wall } \\
\text { intensity } \\
\end{array}$ & $\mathrm{P}_{\mathrm{ww}}$ & $0.94 \mathrm{kN} / \mathrm{m}^{2}$ \\
\hline $\begin{array}{l}\text { Pressure due } \\
\text { to vertical } \\
\text { excitation } \\
\end{array}$ & $\mathrm{P}_{\mathrm{v}}$ & $3.28 \mathrm{kN} / \mathrm{m}^{2}$ \\
\hline $\begin{array}{c}\text { Max. } \\
\text { hydrodynamic } \\
\text { pressure }\end{array}$ & $\mathrm{P}$ & $5.84 \mathrm{kN} / \mathrm{m}^{2}$ \\
\hline \multirow{6}{*}{$\begin{array}{c}\text { Equivalent } \\
\text { linear pressure } \\
\text { distribution }\end{array}$} & $\mathrm{q}_{\mathrm{i}}$ & $52.97 \mathrm{kN} / \mathrm{m}$ \\
\hline & $\mathrm{a}_{\mathrm{i}}$ & $27.76 \mathrm{kN} / \mathrm{m}^{2}$ \\
\hline & $\mathrm{b}_{\mathrm{i}}$ & $14.32 \mathrm{kN} / \mathrm{m}^{2}$ \\
\hline & $\mathrm{q}_{\mathrm{c}}$ & $14.32 \mathrm{kN} / \mathrm{m}$ \\
\hline & $a_{c}$ & $3.67 \mathrm{kN} / \mathrm{m}^{2}$ \\
\hline & $b_{c}$ & $4.90 \mathrm{kN} / \mathrm{m}^{2}$ \\
\hline $\begin{array}{c}\text { Sloshing wave } \\
\text { height }\end{array}$ & $\mathrm{d}_{\max }$ & 0.1008 \\
\hline
\end{tabular}

Table 2: Seismic Analysis Results For Ground Supported Tank 


\section{Results and Discussion}

The result values are computed to determine the graph of reinforced area v/s capacity of tank and the moment v/s capacity of tank. With increase in the capacity of tank the reinforced area and moment increases. The graph of base shear $\mathrm{v} / \mathrm{s}$ impulsive height and overturning moment $\mathrm{v} / \mathrm{s}$ convective height is also determined which shows that as the height increases the time period also changes and as a consequence base shear and overturning moment also changes.

\begin{tabular}{|c|c|c|}
\hline Capacity & $\begin{array}{c}\text { B.M at support } \\
(\mathbf{k N m})\end{array}$ & $\begin{array}{c}\mathbf{A}_{\text {st }} \text { at centre of } \\
\left.\text { span } \mathbf{( m m}^{\mathbf{2}}\right)\end{array}$ \\
\hline 25000 & 12.98 & 602 \\
\hline 30000 & 18.21 & 845 \\
\hline 35000 & 23.59 & 1055 \\
\hline 40000 & 28.82 & 1337 \\
\hline 45000 & 34.04 & 1580 \\
\hline
\end{tabular}

Table 3: Comparison Table For Bending Moment V/S A

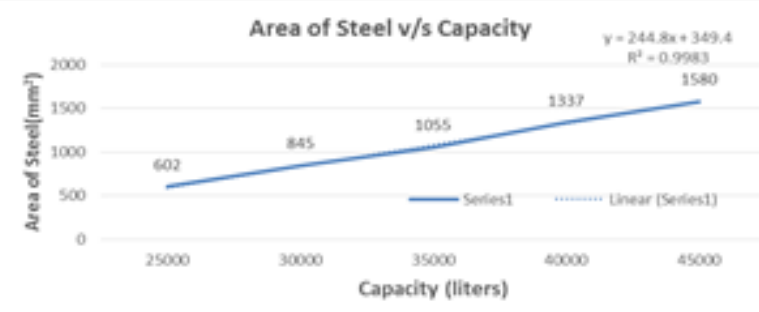

Figure 3: Comparison Graph For Capacity Of Tank V/S A

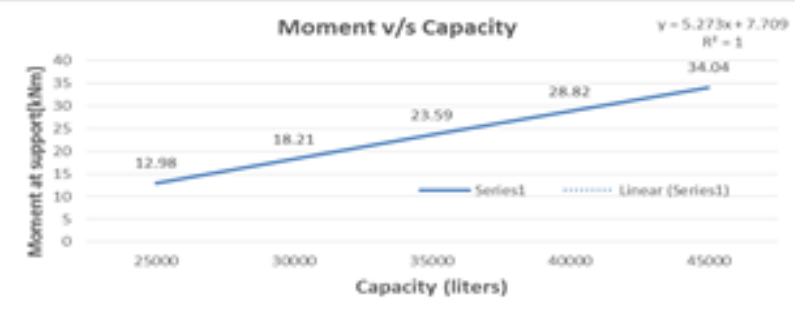

Figure 4: Comparison Graph For Capacity Of Tank V/S Bending Moment

\begin{tabular}{|c|c|c|c|c|}
\hline $\begin{array}{c}\text { Capacity } \\
\text { (liters) }\end{array}$ & $\begin{array}{l}\text { Impulsive } \\
\text { height }\left(h_{i}\right) \\
\text { (m) }\end{array}$ & $\begin{array}{l}\text { Base shear } \\
\text { in } \\
\text { impulsive } \\
\text { mode }\left(V_{i}\right) \\
(k N)\end{array}$ & $\begin{array}{l}\text { Convective } \\
\text { height }\left(h_{c}\right) \\
\text { (m) }\end{array}$ & $\begin{array}{c}\text { Moment } \\
\left(\mathbf{M}_{\mathrm{c}}^{*}\right) \\
(\mathbf{k N m})\end{array}$ \\
\hline 25000 & 0.63 & 455 & 3.34 & 404.33 \\
\hline 30000 & 0.75 & 460 & 4 & 479.93 \\
\hline 35000 & 0.88 & 466 & 4.68 & 557.82 \\
\hline 40000 & 1 & 471 & 5.34 & 633.41 \\
\hline 45000 & 1.13 & 477 & 6 & 709.01 \\
\hline
\end{tabular}

Table 4: Comparison Table For Seismic Analysis Results 


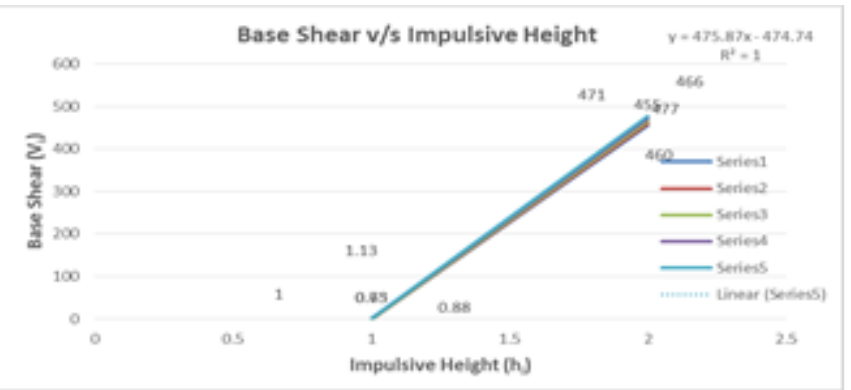

Figure 5: Comparison Graph For Base Shear V/S Impulsive Height Of Tank

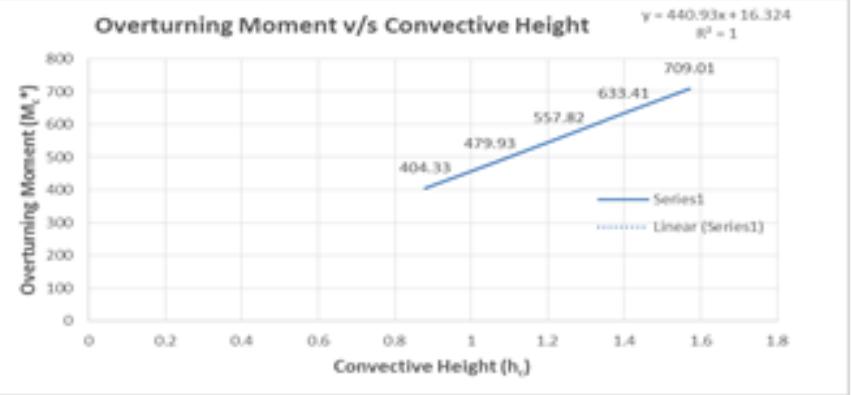

Figure 6: Comparison Graph For Overturning Moment V/S Convective Height

\section{Conclusion}

Design of underground water tank involves tedious mathematical formulae and calculation. It is also time consuming, hence the relationship is derived which can be helpful in deriving the base moment and wall reinforcement as well as the base shear and overturning moment. The relationship gives values of reinforcement area and moment capacity which increases with increase in the tank capacity. On the other hand as the convective and impulsive height increases, overturning moment and base shear increase respectively. These relationships are useful for easy analysis and design for tank. Also understands the seismic behavior of ground supported tank.

\section{References}

[1] IS : 456-2000, Plain and Reinforced Concrete - Code of Practice Bureau of Indian Standards

[2] IS : 1893 (Part I)-2002, General provisions and buildings - Code of Practice Bureau of Indian Standards

[3] IS : 1893-2007 (Part II)-Draft code, Liquid retaining tanks- Code of Practice Bureau of Indian Standards

[4] IS : 3370 (Part II)- 2009, Code of Practice Bureau of Indian Standards for Concrete Structures for Storage of Liquids

[5] IS : 3370 (Part IV)- 1967, Code of Practice Bureau of Indian Standard for Concrete Structures for Storage of Liquids, Design Tables

[6] Dr. H.J. Shah(2012),'Reinforced Concrete Volume 2", $9^{\text {th }}$ Edition 